\title{
Synchronization of GnRH and PGF2 $\alpha$ on estrus response, pregnancy, progesterone hormones in crossing of Swamp Buffalo and Water Buffalo in West Sumatra, Indonesia
}

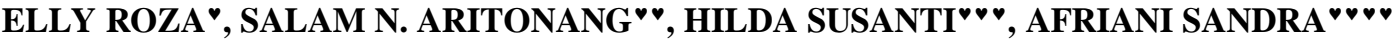 \\ Faculty of Animal Science, Universitas Andalas. J1. Lingkar Unand, Kampus Limau Manih, Pauh, Padang 25163, West Sumatra, Indonesia. Tel.: +62-

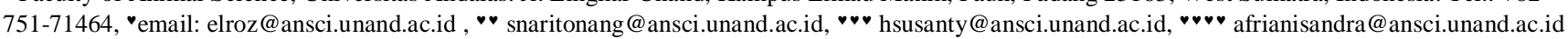

Manuscript received: 31 July 2019. Revision accepted: 9 September 2019.

\begin{abstract}
Roza E, Aritonang SN, Susanti H, Sandra A. 2019. Synchronization of GnRH and PGF2a on estrus response, pregnancy, progesterone hormones in crossing of swamp buffalo and water buffalo in West Sumatra, Indonesia. Biodiversitas 20: 2910-2914. This study aims to determine the effect of GnRH and PGF2 $\alpha$ synchronization on estrus emergence, pregnancy percentage, progesterone hormone levels and blood profile from artificial insemination (AI) of swamp and water buffalo crossing in Sijunjung, West Sumatra. The samples were 21 female swamp buffaloes with criteria clinically healthy, age $\geq 2.5$ years and not pregnant. All buffalos on the first day were synchronized using $250 \mu \mathrm{gGnRH}$ (Fertagyl ${ }^{\circledR}$, Intervet International). All of the buffaloes received $12.5 \mu \mathrm{g}$ PGF2 $\alpha$ on the seventh day after GnRH injection. On the second day after injection of PG2 $\alpha$, the observation of estrus was carried out, the buffalos with estrus symptoms appeared after performing AI for 18 hours which the estrus symptoms was seen using a 0.5 ml Murrah buffalo semen with a sperm concentration of 500 million. Blood serum of 3-5 ml for the examination of progesterone levels was taken on days 21, 24, and 27 after appeared in AI. Hormone analysis was performed using the Enzyme-Linked Immunoabsorbent Assay (ELISA) method. The variables measured were the percentage of estrus, pregnancy, progesterone hormone levels, and blood profile. Pregnancy examination (PE) was carried out after 90 days in AI through rectal palpation. The data were analyzed descriptively. The results showed synchronization of GnRH and PG2 $\alpha$ hormones in buffalo cattle which had $100 \%$ estrus, $66.67 \%$ pregnancy after AI, pregnant buffalo progesterone concentration $5.09-8.87 \mathrm{ng} / \mathrm{mL}$ and non-pregnant $1.11-3.45 \mathrm{ng} / \mathrm{mL}$, total blood protein $7.9 \mathrm{~g} / \mathrm{L}$ and blood glucose 86.86 $\mathrm{mg} / \mathrm{dL}$. The conclusion of this study is that the combination of GnRH and PG2 $\alpha$ gives a clear appearance of estrus, progesterone hormone levels, and optimal buffalo blood profile.
\end{abstract}

Keywords: Artificial insemination, estrus, GnRH and PGF2 $\alpha$ synchronization, progesterone, swamp, water buffalo crossing

\section{INTRODUCTION}

In West Sumatra, Indonesia, buffalo cattle act as a producer of meat, milk, labor and a complement in traditional ceremonies. As a milk producer, the role of buffaloes is quite important, contributing to $12.8 \%$ of world milk production (FAOSTAT 2015). Buffalo milk production is still low with an average of 1-2 liters/day (Ibrahim 2008 dan Roza et al. 2017) because most of the buffalos used for milk production are not swamp/water type buffalo. Water buffalo is a milk-producing buffalo that is only found in North Sumatra Province and needs to be conserved as local livestock germplasm considering its population is less than 1000 individuals. Water buffalo has the potential as a milk producer developed in tropical regions such as Indonesia because of its high adaptability. Buffalo milk has the advantage of the fat content of $6-10 \%$ and protein $4-6 \%$ compared to the fat and protein content of cow's milk by 3 $4 \%$ and water buffalo milk production ranging from 6-8 liters/head/day ( Mihaiu et al. 2011; Roza et al. 2015).

Buffalo cattle have enormous potential to be developed in Indonesia to increase national milk availability. The population of buffalo in 2008 was 2.2 million, of which more than half $(51 \%)$ were on the island of Sumatra. During the last five years (2011-2015), the population of buffalo in West Sumatra has fluctuated and tends to increase by around $18.8 \%$ (Direktorat Jenderal Peternakan, 2015). This proves that the natural and socio-cultural conditions of the people of Sumatra Island provide a decent place for the development of buffalo cattle. The buffaloes that many Indonesians maintain are swamp buffalos that are not dairy types even though in some areas farmers do milking.

To increase the production of meat and buffalo milk, it is necessary to make genetic improvement efforts through selection and cross-breeding. Increasing productivity of buffaloes through cross-breeding has not much done in Indonesia. Buffaloes from the cross-breeding process produce high-quality meat and produce more milk than their mothers. The main obstacle that inhibits the productivity of buffaloes so that the calving interval is longer because the heat of buffalo is not easily identified (silent heat), so it is difficult to detect the heat (Senger 2005; De Rensis dan Lopez-Gatius 2007). One way to overcome this problem is by applying reproductive biotechnology, namely the technique of estrus synchronization using the hormones of GnRH, FSH and Progesterone and Prostaglandin (PGF2 $\alpha$ ), whose purpose is to manipulate progesterone to the lowest level (De Rensis dan Lopez-Gatius 2007). 
Progesterone is one of the important reproductiverelated hormones secreted by Luteal corpus luteum (CL) cells (Hafez and Hafez 2000). Corpus luteum is an endocrine organ that is responsible for producing the hormone progesterone. Blood serum progesterone concentration can determine the state of the animal in an infertile, normal, estrus, or pregnant state so that it can be used for estrus detection, pregnancy examination and knowing other pathological conditions. Early pregnancy diagnosis based on progesterone hormone concentrations has been carried out in cattle (Amiruddin et al. 2001).

The AI program for synchronizing estrus in buffalo cattle is essential. The advantages of estrus synchronization include increasing reproductive efficiency (Herdis 2011). Several studies have been conducted on buffalo abroad using GnRH and PGF2 $\alpha$ as a method of synchronization in Mediterranean buffalo (Berber et al. 2002), Egyptian buffalo (Bartolome et al. 2002) and Italian buffalo (Neglia et al. 2003).

but in other countries such as the Philippines, China, Australia, Vietnam, and Bangladesh, a lot has been done to get dual-purpose buffaloes. Crossing of swamp buffalo and water buffalo is conducted to form new breeds with a genetic composition of water buffalo above $32.5 \%$. The productivity of crossing between $32.5 \%$ water buffalo $67.5 \%$ and swamp buffalo results on $40 \%$ body weight which is higher than swamp buffalo (Lemcke 2004). The buffalo produced by this crossing method is a strong working animal, produces high-quality meat and produces more milk than its mothers. The purpose of this study was to detect estrus, pregnancy, and progesterone hormone levels after synchronization of GnRH and PGF2 $\alpha$ in crossing swamp and water buffalos in Sijunjung, West Sumatra.

\section{MATERIALS AND METHODS}

The material used was female swamp buffalo milked in Pematang Panjang village, Sijunjung District, West Sumatra with the total number of 21 , aged $\geq 2.5$ years old with GnRH hormones (Fertagyl ${ }$, Intervet International, Europe) and PG2 $\alpha$ (Noroprost ${ }^{\circledR}$ Noorbrok, Northern Ireland).

This study uses an experimental method in buffalo cattle which produce dadih/dadiah in Pematang Panjang village, West Sumatra. The location and breeder selection uses purposive sampling method. The buffalo used by the selection was based on good health; reproduction was not interrupted and was not pregnant, carried out by health workers and sub-district staff of Artificial Insemination (AI).

On the first day, the female buffalos were injected with GnRH (Fertagyl@, Intervet International, Europe) intramuscularly ( $\mathrm{I} \mathrm{m}$ ) with the total number of 250 $\mu \mathrm{g} / \mathrm{head}$. On the seventh day $12.5 \mathrm{mg}$ of PG2 $\alpha$ was injected (Noroprost ${ }^{\circledR}$ Noorbrok, Northern Ireland) intramuscularly (I m). On the second day after injection of PG2 $\alpha$, the observation of estrus was carried out. According to Siregar (2008), symptoms in buffaloes are generally not as clear as in cows, which are characterized by changes in the external genitals, vulva reddened, swollen and mucus coming out and changes in behavior. AI could be done after 18 hours of estrus symptoms seen using a $0.5 \mathrm{ml}$ Murrah buffalo semen with a sperm concentration of 500 million. The frozen semen used was from the North Sumatra Artificial Insemination Center. On the $21^{\text {st }}, 24^{\text {th }}$ and $27^{\text {th }}$ day, 3-5 ml of blood was taken from each buffalo. Blood sampling was performed by manual technique using a venoject needle and vacuum tube, assisted by technicians from the local Animal Science Office. Pregnancy examination was conducted through rectal palpation 90 days after AI. The tools used were AI equipment, syringes, and venoject for collecting buffalo blood, coolboxes, kit and chemicals for analysis of blood and progesterone hormones. Blood samples were taken to the Biomedical Laboratory of the University of Andalas Medical School in Padang to analyze blood progesterone concentrations with the EnzymeLinked Immunosorbent Assay (ELISA) method using a progesterone kit (Diagnostic Products Corporation, Los Angeles, CA), and test sensitivity of 0.24 n.mol/liter (Technical Reports Series 1984). Moreover, blood profile analyzed using the Reflotron Plus method with modification of Reflovet Plus (Roche).

Variables measured: percentage of estrus, percentage of pregnancy, pregnancy number by looking at the number of pregnant females divided by the number of inseminated females multiplied by $100 \%$, progesterone hormone levels, protein and blood glucose levels. The data obtained were analyzed descriptively by displaying percentages, calculating averages and standard deviations (Sudjana 2005).

\section{RESULTS AND DISCUSSION}

The results of observing the percentage of estrus in synchronized buffalo with GnRH and PG $2 \alpha$ show excellent results for the appearance of $100 \%$ estrus (Table 1), marked by discoloration of the vulva to red and swollen, mucous discharge from the vulva and changes in animal behavior to become agitated. This shows that the using of GnRH together with PG2 $\alpha$ has synchronized for buffalo to be estrus, because GnRH will stimulate FSH to stimulate follicle growth and followed by LH to ovulate form Corpus Luteum (CL) and respond well to PG2 $\alpha$. According to Metwelly et al. (2001) and Irikura et al. (2003) statement that the consequence of GnRH and PG2 $\alpha$ combination in heafers and adult buffaloes make them be estrus (100\%). The results of this study are similar to those of Yendraliza et al. (2012) that the giving of $300 \mu \mathrm{gGnRH}$ synchronized with $12.5 \mathrm{mg}$ PGF2 $\alpha$ can show signs of estrus in postpartum buffalo cattle with a percentage of pregnancy $100 \%$. This is confirmed by Neglia et al. (2003), Paul and Prakash (2005) that the combination of the use of GnRH and PGF2 $\alpha$ will accelerate the emergence of heat in buffalo.

This situation shows that the reproductive conditions of acceptor animals are fertile and have a regular reproductive cycle so that they respond well to the PGF $2 \alpha$ hormones. 
Brito et al. (2002) reported that reactivation of prostaglandin hormone (PGF2 $\alpha$ ) to livestock that has regular cycles in the luteal phase would be effective in stimulating estrus, due to the nature of prostaglandins which lyses CL. Generally, the luteal phase (diestrus phase) is around 17 days from the buffalo estrus cycle (on average of 21-22 days), so it is estimated that in one buffalo population, female buffaloes in the luteal phase can reach 60-80\% (De Rensis dan Lopez-Gatius 2007). Estrus caused by $\mathrm{Gn}-\mathrm{RH}$, which is responsible to stimulating $\mathrm{FSH}$ release. $\mathrm{FSH}$ has an important role to stimulate follicle growth in the ovary. The growth of follicles will stimulate estrogen formation. According to Fricke and Shaver (2007), the emergence of estrus is caused by the effect of increasing the hormone estrogen in the body produced by the ovum. Hafez (2000) Gn-RH which functions to stimulate the release of FSH and $\mathrm{LH}$ in anterior pituitary will stimulate the development of Follicle and ovulation and the formation of the corpus luteum. Rajamahendran et al. (2002) stated that the number of recruited follicles to develop further to de Graaf is highly dependent on FSH concentration in the blood.

\section{Percentage of pregnancy and hormone levels of progesterone}

The hormone progesterone is one of the reproductive hormones that are very important in the sexual development and reproductive performance of female mammal. The concentration of the hormone progesterone in blood of Pregnant and not pregnant swamp buffalo in AI after estrus synchronization can be seen in Table 1 .

According to Table 1, the results of pregnancy examination by looking at the concentration of the progesterone hormone carried out on $21^{\text {st }}, 24^{\text {th }}$ and $27^{\text {th }}$ day after AI showed that from 21 swamp buffaloes in AI with Murrah buffalo frozen semen, 14 of them (66.67\%) got pregnant, and 7 were not pregnant $(33.33 \%)$. Buffalos that are not pregnant may be due to the condition that is different from the pregnant one, which is the first time pregnant, while the pregnant cattle have given birth two and three times. This is supported by Belstra (2003) that parity is positively correlated with the life span or age of livestock. The pregnancy rate is similar to the results of research by Lietman et al. (2009) which reached $61 \%$.

Pregnancy testing and the ability of progesterone to maintain pregnancy are more effective if it is conducted on the $21^{\text {st }}$ day or more after AI is performed because progesterone levels at that time have stabilized. In pregnant animals, the level of progesterone hormone will tend to be high while the non-pregnant cattle have lower levels. Thus, no embryonic death occurs after the 21 st day after on AI can be used as pregnancy indicator.

In Figure 1 it shows that the concentration of progesterone continues to increase from day 21, 24 and 27 days after IB. On the 21st day after at AI the lowest hormone progesterone concentration was $5.09 \mathrm{ng} / \mathrm{mL}$ and the 27th day after AI was increased to $7.41 \mathrm{ng} / \mathrm{mL}$. This condition showed that buffaloes were likely to have the pregnancy and could be maintained until the 60th day because of the CL activity that produced the progesterone hormone. The results of this study are similar with the results of McDonald (2000) that the progesterone levels in pregnant cows levels above $6.6 \mathrm{ng} / \mathrm{mL}$ while not at the time of pregnancy were $0,1-2,2, \mathrm{ng} / \mathrm{mL}$ (Muhamad et al. 2000). In a study of Korean cows (Hanwoo) Ryu et al. (2003) found that progesterone levels in pregnant cows were more than $3 \mathrm{ng} / \mathrm{mL}$ while those that were Not-pregnant were less than two $\mathrm{ng} / \mathrm{mL}$. The concentration of progesterone in blood plasma decreases $60.42-50.88 \mathrm{nmol} / \mathrm{L}$ and in the last month of pregnancy it was $1.59-9.54 \mathrm{nmol} / \mathrm{L}$ at the time of delivery (Ginther et al. 2010). Concentration non-pregnant cow progesterone typically decreases on day 17 to 20 of the estrus cycle, while pregnant cows, progesterone concentrations continue to be maintained until close to the end of pregnancy. According to Frandson (1996), progesterone can cause thickening of the endometrium and the development of the uterine gland preceding the implantation of the fertilized ovary.

Table 1. Percentage of estrus, levels of progesterone and hormones of pregnant and non-pregnant buffalo swamps inseminated artificially after estrus synchronization

\begin{tabular}{|c|c|c|c|c|}
\hline \multirow[t]{2}{*}{ No. } & \multirow[t]{2}{*}{ PE } & \multicolumn{3}{|c|}{$\begin{array}{l}\text { Progesterone hormone profile } \\
\text { (ng / mL) after AI (day) }\end{array}$} \\
\hline & & 21 & 24 & 27 \\
\hline 1 & Pregnant & 5.87 & 6,22 & 8.69 \\
\hline 2 & Not-pregnant & 2.22 & 2.41 & 1.92 \\
\hline 3 & Pregnant & 5.32 & 5.61 & 7.13 \\
\hline 4 & Pregnant & 5.78 & 5.99 & 7.02 \\
\hline 5 & Not-pregnant & 1.29 & 1.11 & 0.89 \\
\hline 6 & Not-pregnant & 2.68 & 2.27 & 1.07 \\
\hline 7 & Pregnant & 5.61 & 6.70 & 8.07 \\
\hline 8 & Pregnant & 5.58 & 6.84 & 7.75 \\
\hline 9 & Pregnant & 5.21 & 6.34 & 8.62 \\
\hline 10 & Pregnant & 5.09 & 5.98 & 7.41 \\
\hline 11 & Not-pregnant & 2.13 & 2.76 & 1.99 \\
\hline 12 & Pregnant & 5.35 & 6.57 & 7.98 \\
\hline 13 & Not-pregnant & 1.57 & 2.34 & 3.45 \\
\hline 14 & Pregnant & 5.87 & 7.03 & 8.87 \\
\hline 15 & Pregnant & 5.65 & 6.79 & 8.03 \\
\hline 16 & Not-pregnant & 1.62 & 2.51 & 1.89 \\
\hline 17 & Not-pregnant & 2.34 & 3.22 & 2.45 \\
\hline 18 & Pregnant & 5.69 & 7.12 & 8.48 \\
\hline 19 & Pregnant & 5.90 & 6.91 & 8.37 \\
\hline 20 & Pregnant & 5.41 & 6.89 & 8.35 \\
\hline 21 & Pregnant & 5.19 & 7.02 & 8.57 \\
\hline
\end{tabular}

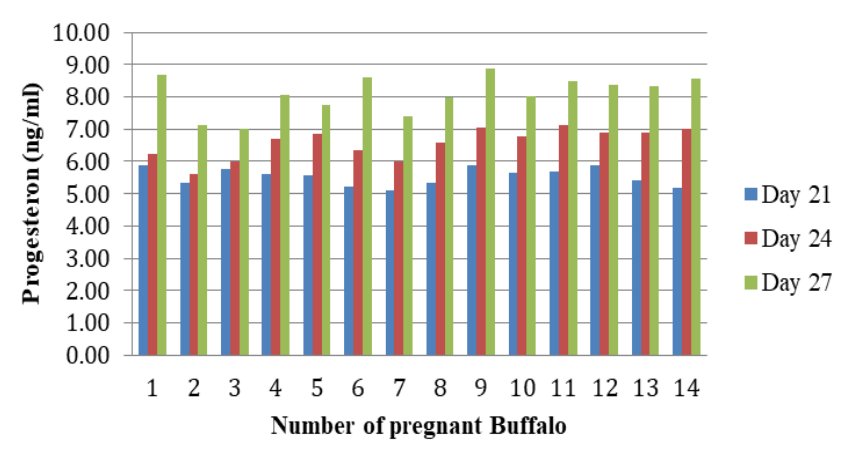

Figure 1. Progesterone hormone in pregnant buffalo 


\section{Total of protein and blood glucose}

The results of this study indicate that the total blood protein of pregnant buffalo is quite high, namely $7.19 \mathrm{~g} / \mathrm{dl}$. This indicates that sufficient total serum blood protein concentration in pregnant buffalo is a sign that the buffalo has sufficient protein in the ration so that the amino acids are working for the biosynthesis of gonadotropins and the gonadal hormone (Kesler et al. 1979).

The biochemical profile of blood serum, especially the level of total protein and blood glucose levels indicates the fulfillment of nutrients in the rations given, both in terms of quality and quantity. Such conditions are very influential in the reproductive system. According to Pradhan and Nakagoshi (2008) cows fed with low-quality nutrition have a significant influence on the state of reproduction. Nutritional deficiencies in the ration can affect the ovulation and fertilization process, affecting the development of the embryo and fetus in the uterus, so that causing embryonic death and absorption of the embryo by the uterine wall, abortion or the birth of a weak child and neonatal death (Jainudeen dan Hafez 2000; Bearden et al. 2004).

The results show that the concentration of glucose in the blood serum of pregnant buffalo was quite high at $86.68 \mathrm{mg} / \mathrm{dL}$. The high serum glucose levels in pregnant buffalo indicate high energy (carbohydrates) in the ration. This study supports the opinion of Chandrahar et al. (2003), that pregnant dairy cows have high blood glucose levels. The blood glucose level of swamp buffalo in this study was higher than that of buffalo blood glucose levels reported by Fahlevi et al. (2017), which ranged from 34,00$114,00 \mathrm{mg} / \mathrm{dL}$. The high blood glucose level indicates the fulfillment of nutrients in the rations given and affects reproduction. If blood glucose levels in the serum are low, besides being able to inhibit the synthesis or release of gonadotropin-releasing hormone $(\mathrm{GnRH})$ it also inhibits the release of follicle-stimulating hormone (FSH) and luteinizing hormone (LH), causing obstruction of follicle, ovum, estrogen and progesterone development. Nutritional deficiencies also have an impact on the death of the ovum, embryo, and fetus due to insufficient ovarian steroid hormones.

Glucose is one of the most critical metabolic substrates needed for functions that are compatible with reproductive processes in buffalo. The low serum glucose levels not only can cause high concentrations of non-esterified fatty acids (NEFA) which have toxic effects on follicles, oocytes, embryos, and fetuses (Murray et al. 2003), and decreased hypothalamic GnRH secretion (Murray et al. 2003), but also decrease GnRH which inhibits FSH and LH synthesis and cause recurrence of mating (Mulligan et al. 2006).

To conclude, the results show that the injection of GnRH hormone combined with PG2 $\alpha$ in buffalo livestock gave $100 \%$ estrus appearance; pregnant buffalo progesterone concentration $5.32-8.69 \mathrm{ng} / \mathrm{mL}$ and nonpregnant $1.11-2.68 \mathrm{ng} / \mathrm{mL}$ with pregnancy percentage of $62.5 \%$, total blood protein $7.9 \mathrm{~g} / \mathrm{L}$ and blood glucose 86.86 $\mathrm{mg} / \mathrm{dL}$. Combination of $\mathrm{GnRH}$ and $\mathrm{PG} 2 \alpha$ gives rise to estrus and progesterone concentration and optimal buffalo blood profile.

\section{ACKNOWLEDGEMENTS}

We sincerely thank the Institute for Research and Community Services, Andalas University, Padang, Indonesia. This study was funded by the program of Skim Klaster Riset Percepatan Guru Besar in accordance with Contract Number: 44/UN.16.17/PP.PGB/LPPM/2018 Fiscal Year 2018.

\section{REFERENCES}

Amiruddin TN, Siregar, Budiman H. 2001. Efektivitas beberapa metode diagnosis. J Med Vet 1 (2): 45-48. [Indonesian]

Bartolome JA, Silvestre FT, Artechte ACM, Kamimura S, Archbald LF, Thatcher WW. 2002. The use of ovsynch and heatsynch for resynchronization of cows open at pregnancy diagnosis by ultrasonography. J Dairy Sci 81: 390-342.

Bearden JH, John WF, Scott TW. 2004. Applied Animal Reproduction. $6^{\text {th }}$ ed. Pearson, New Jersey.

Belstra BA. 2003. Parity associated changes in reproductive performance: Physiological basis and record-keeping artifact. www.mark.asci..ncsu.edu/swine report/2003/belstra.htm.

Berber RCA, Madureira EH, Barusselli PS. 2002. Comparison of two ovsynch protocols ( $\mathrm{GnRH}$ vs. LH) for fixed timed insemination in buffalo (Bubalus bubalis). Theriogenology 57: 1421-1430.

Brito LFC, Satrapa R, Marson EP, Kastelic JP. 2002. Efficacy of PGF2 $\alpha$ to synchronize estrus in water buffalo cows (Bubalus bubalis) is dependent upon plasma progesterone concentration, corpus luteum size and ovarian follicular status before treatment. Anim Reprod Sci 73: 23-35.

Chandrahar D, Tiwari RP, Awasthi MK, Dutta GK. 2003. Serum biochemical profile of repeat breeder cows. Indian J Anim Reprod 24: 125-127.

De Rensis F, Lopez-Gatius F. 2007. Protocols for synchronizing estrus and ovulation in buffalo (Bubalus bubalis): A review. Theriogenology 67: 209-216.

Direktorat Jenderal Peternakan dan Kesehatan Hewan. 2015. Statistik peternakan 2015. Direktorat Jenderal Peternakan. Departemen Pertanian, Jakarta. [Indonesian]

Fahlevi1 Z, Al Azhar, Sayuti A, Isa M, Adam M, Herrialfian. 2017. Blood chemistry of local swamp buffaloes (Bubalus bubalis) of Aceh. J Medika Vet 11 (1): 66-70. [Indonesian]

FAOSTAT. 2012. Statistical database. http://faostat.fao.org/.

Frandson RD. 1996. Anatomi dan Fisiologi Ternak. Gajah Mada University Press, Yogyakarta. [Indonesian]

Fricke PM, Shaver RD. 2007. Managing reproductive disorders in dairy cows. www.wisc.edudysciuwexrep.

Ginther OJ, Shrestha HK, Fuenzalida MJ, Shahiduzzaman AK, Hannan MA, Beg MA. 2010. Intrapulse temporality between pulses of a metabolite of prostaglandin F2á and circulating concentrations of progesterone before, during, and after spontaneous luteolysis in heifers. Theriogenology 74: 1179-1186.

Hafez ESE, Hafez B. 2000. Reproduction in Farm Animals. $7^{\text {th }}$ ed. Lippincott William and Wilkins, Maryland.

Hafez ESE. 2000. Anatomy of Male Reproduction. A Wolter Kluwer Company, Lippincott William \& Wilkins, Maryland.

Herdis. 2011. Respon estrus domba garut betina pada perlakuan laserpuntur dengan fase reproduksi yang berbeda. J Sains Teknol Indonesia 13 ( 3): 171-176. [Indonesian]

Ibrahim L. 2008. Produksi susu, reproduksi dan manajemen kerbau perah di Sumatera Barat. J Peternakan 5 (1): 1-9. [Indonesian]

Irikura CR, Ferreira JCP, Martin I, Cimenes LU, Oba E, Jorge AM. 2003. Follicular dynamics in buffalo heifers (Bubalus bubalis) using the GnRHPGF2 $\alpha$-GnRH protocol. Buffalo J 3: 323-327.

Jainudeen MR, Hafez ESE. 2000. Reproductive Failure in Females. In: Hafez ESE (eds.). Reproduction in Farm Animal. 7th ed. Lea and Febiger, Philadelphia.

Kesler DJ, Garberick HA, Bierschwal CJ, Elmore RG, Youngqvist RS. 1979. Reproductive hormones associated with normal and abnormal changes in ovarian follicles in postpartum dairy buffalo. J Dairy Sci 62 (8): 1290-1296. 
Leitman NR, Busch DC, Mallory DA, Wilson DJ, Ellersieck MR, Smith MF, Patterson DJ. 2009. Comparison of long-term CIDRbased protocol to synchronize estrus in beef heifers. Anim Reprod Sci 114: 345-355.

Lemcke B. 2004. Production specialized quality meat products from water buffalo: Tenderbuff. The Carabao-Bubalus Bubalis carabanensis. Proceedings $7^{\text {th }}$ World Buffalo Congress. Makati City, Philippines, 20-23 October 2004.

McDonald LE. 2000. Veterinary Endocrinology and Reproduction. 3rd ed. Bailliere Tindall, London.

Metwelly KK. 2001. Postpartum anestrus in buffalo cows; cause and treatment. Proc 7th Sci Congr Egypt Soe Cattle Disease, Assiut University, Egypt.

Mihaiu M, Lapusan A, Bele C, Mihaiu R. 2011. compositional particularities of the Murrah hybrid buffalo milk and its suitability for processing in the traditional system of Romania. Bul UASVM, Vet Med 68 (2): 216-221.

Muhamad F, Sawar A, Hayat CS, Anwar MI. 2000. Peripheral plasma progesterone concentration during early pregnancy in Holstein Friesian cows. Pak Vet J 20 (4): 166-168.

Mulligan FJ, O'Grady L, Rice DA, Doherty ML. 2006. Nutrition and fertility in dairy cows. Irish Vet J 60: 15-20.

Murray RK, Granner DK, Mayes PA, Rodwell VW. 2003. Harper's Illustrated Biochemistry. 25th ed. McGraw Hill Professional, New York.

Neglia G, Gasparrini B, Palo RD, Rosa CD, Zicarelli L, Campanile G. 2003. Comparison of pregnancy rates with two oestrus synchronization protocols in Italian Mediterranean buffalo cows. Theriogenology 60: 125-133.
Paul V, Prakash B. 2005. Efficacy of the ovsynch protocol for synchronization of ovulation and fixed-time artificial insemination in Murrah buffaloes (Bubalus bubalis). Theriogenology 64: 1049-1060.

Pradhan R, Nakagoshi N. 2008. Reproductive disorders in cattle due to nutritional status. J Intl Dev Coop 14: 45-66.

Rajamahendran R, Ambrose JD, Aali M, Rramakrishnappa N, Giritharan N, Small J. 2002. Hormonal treatment following breeding to increase pregnancy rates in cattle. J Biotech Anim Reprod 9: 151-160.

Roza E, Aritonang SN, Lendrawati. 2017. Kajian gambaran darah dan karakteristik susu kerbau sungai dan kerbau rawa dalam pencapaian swasembada susu 2020. Laporan Penelitian BOPTN, Universitas Andalas, Padang. [Indonesian]

Roza E, Aritonang SN, Sandra A. 2015. The haematology of lactating buffalo fed local foilage as feed supplement. J Agric Sci Technol A 5 (10): 839-845.

Ryu YH, Yang JY, Seo DS, Ko Y. 2003. Effect of serum IGF-I on progesterone concentration during early pregnancy in Korean native cattle (hanwoo). Asian-Aust J Anim Sci 16 (2): 176-179.

Senger PL. 2005. Reproductive cyclicity-the follicular phase. In: Pathways to Pregnancy and Parturition. $2^{\text {nd }}$ Revised Edition. Current Conceptions Inc., Washington State University Research \& Technology Park, Seattle, WA.

Siregar TN. 2008. Upaya meningkatkan intensitas berahi pada kerbau dalam hubungannya dengan peningkatan angka konsepsi hasil inseminasi buatan. J Ilmiah Ilmu-Ilmu Peternakan 11 (4): 69-74. [Indonesian]

Sudjana. 2005. Metode Statistika. Trasito, Bandung. [Indonesian]

Yendraliza, Zespin BP, Udin Z, Jaswandi. 2012. Post-partum reproductive appearance of buffalo at various levels of GnRH and synchronized with PGF2 $\alpha$. JITV 17 (2): 107-111. [Indonesian] 